\title{
Adult Wilms' Tumor: A Rare Case Report
}

\author{
Erişkin Wilms Tümörü: Nadir Bir Olgu Sunumu
}

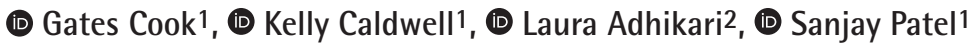 \\ 1 University of Oklahoma Health Sciences Center, Department of Urology, Oklahoma City, Oklahoma, USA \\ 2University of Oklahoma Health Sciences Center, Department of Pathology, Oklahoma City, Oklahoma, USA
}

\begin{abstract}
Wilms' tumor is one of the most common intraabdominal malignancies among children and treatment protocols have been well studied in this population. The clinical presentation differs between the pediatric and adult populations with adults presenting similar to patients with renal cell carcinoma. Diagnosis is usually made by surgical pathology as imaging cannot differentiate between Wilms' tumor and other kidney pathologies. In addition to surgical excision, treatment includes systemic chemotherapy and/or radiation. In this case report, we present a patient who underwent successful surgical resection of a $29 \times 24 \times 25 \mathrm{~cm}$ right-sided Wilms' tumor with subsequent chemotherapy and radiation.
\end{abstract}

Keywords: Wilms' tumor, Adult Wilms' tumor, Kidney malignancy

\section{Öz}

Wilms tümörü, çocuklar arasında en yaygın intraabdominal malignitelerden biri olup, bu popülasyonda tedavi protokolü iyi çalışılmıştır. Klinik görünüm çocuk hastalarla yetişkin hastalar arasında farklılık gösterir. Yetişkin hastaların semptom ve bulguları daha çok renal hücreli kanser hastaları gibidir. Tanı genellikle cerrahi patoloji ile yapılır, çünkü görüntüleme Wilms tümörünü diğer böbrek patolojisinden ayırmaz. Tedavi, cerrahi eksizyona ek olarak, sistemik kemoterapi ve/veya radyasyon içerir. Bu olgu sunumunda, 29x24×25 cm boyutlarında sağ renal taraflı bir Wilms tümörüne, kemoterapi ve radyasyon ile takip eden başarılı bir cerrahi rezeksiyon uygulanmış bir hasta sunulmuştur.

Anahtar Kelimeler: Wilms tümörü, Erişkin Wilms tümörü, Böbrek malignitesi

\section{Introduction}

Wilms' tumor, also known as nephroblastoma, is a common intraabdominal malignancy in young children with most cases occurring before age 5 . The incidence of Wilms' tumor in adults is reported at 0.2 per million per year (1). As opposed to children, who usually present with a palpable abdominal mass, adults tend to present with flank pain and hematuria.

Adult Wilms' tumor has well known diagnostic criteria which include: 1) primary renal neoplasm, 2) presence of primitive blastemic spindle or round cell component, 3) formation of abortive tubules or glomerular structures, 4) no area of tumor diagnostic of renal cell carcinoma, 5) pictorial confirmation of histology, and 6) patient age $>15$ years (2). Due to the rarity of adult Wilms' tumor, the current standard of care regarding treatment is based on well-developed pediatric treatment protocols (3). We present a 41-year-old female who presented with a $29 \times 24 \times 25 \mathrm{~cm}$ right-sided Wilms' tumor.

\section{Case Presentation}

A 41-year-old Caucasian female presented with rapidly increasing abdominal girth and early satiety with a computed tomography (CT) scan demonstrating a $29 \times 24 \times 25 \mathrm{~cm}$ multicystic, multiloculated right-sided abdominal mass with extension into the pelvis (Figure 1). The patient was a non-smoker with a past medical history of obesity and no prior genitourinary problems. Past surgical history included laparoscopic hysterectomy and C-section. Oncologic family history was significant for leukemia and male breast cancer. Physical exam revealed a non-tender, protruding mass of the entire right abdomen. A screening chest CT showed no evidence of metastatic disease. The patient underwent an exploratory laparotomy with right nephrectomy and retroperitoneal mass excision. A multiloculated, cystic,

Correspondence: Gates Cook MD, University of Oklahoma Health Sciences Center, Department of Urology, Oklahoma City, Oklahoma, USA Phone: 405-271-6900 E-mail: gates-c-cook@ouhsc.edu ORCID-ID: orcid.org/0000-0001-6458-6053

Received: 28.09.2017 Accepted: 17.11.2017

Cite this article as: Cook G, Caldwell K, Adhikari L, Patel S. Adult Wilms' Tumor: A Rare Case Report. J Urol Surg 2018;5(4):205-207.

๑ Copyright 2018 by the Association of Urological Surgery / Journal of Urological Surgery published by Galenos Publishing House. 
friable mass arising from the collecting system of the right kidney was found intraoperatively with minimal invasion into the surrounding structures. Due to the friability of the tumor, spillage of cystic fluid occurred. The right ovary was found to be involved in the mass and was subsequently removed. The patient had an uneventful postoperative course and was discharge home on postoperative day 5 without requiring any blood transfusions. The patient had no major/minor complications related to the surgical intervention.

Intraoperative gross pathological review of the mass revealed a large pale solid and cystic mass originating from the right renal pelvis which was perforating through the lower pole of the right kidney (Figure 2). Microscopic pathological review revealed epithelial lined cystic spaces with a primitive population of cells resembling a cambium layer beneath the epithelium consistent with favorable histology, stromal predominant Wilms' tumor (Figure 3). The margins were noted to be positive for tumor and fluid cytology showed similar stromal predominant malignantappearing cells. The right ovary removed during the procedure demonstrated a serous cystadenoma. Per pediatric staging, the patient was diagnosed with stage 3 Wilms' tumor due to positive tumor margins and tumor spillage intraoperatively (4).

Based on the diagnosis of stage 3, favorable histology, Wilms' tumor, the patient was started on multidrug chemotherapy that consisted of doxorubicin, dactinomycin, and vincristine. She also underwent whole abdomen radiation per the COGAREN0532 DD4A protocol set forward by the Children's Oncology Group which includes the National Wilms' Tumor Study Group (NWTS) (5). Repeat CT chest/abdomen/pelvis three months postoperatively showed no evidence of tumor recurrence.

Written informed consent was completed by this patient.

\section{Discussion}

Wilms' tumor is one of the most common intraabdominal malignancies in pediatric patients, but continues to be a rare occurrence in adult patients. The presentation between adults and children is variable. Unlike children who present with a palpable abdominal mass, adults present with painless hematuria, weight loss, decreased performance status and flank pain (6). The diagnosis of Wilms' tumor in adults is almost uniformly made from surgical pathology. CT imaging is non-specific and can mimic other forms of benign and malignant renal tumors including multicystic nephroma, renal cell carcinoma, sarcoma, liposarcoma, gastrointestinal stromal tumor, and other renal tumors.

The management and treatment of adult Wilms' tumor is customarily multimodal and includes surgical, multi-drug chemotherapy and/or radiation. Treatment protocols are

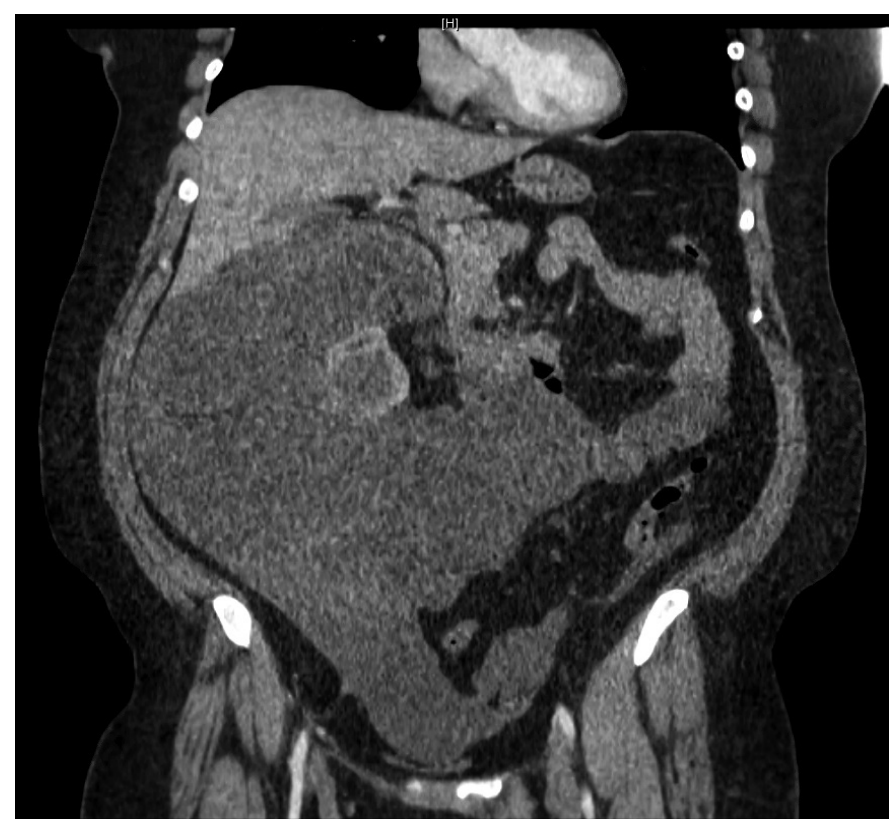

Figure 1. Coronal section of computed tomography abdomen demonstrating large mass arising from right kidney

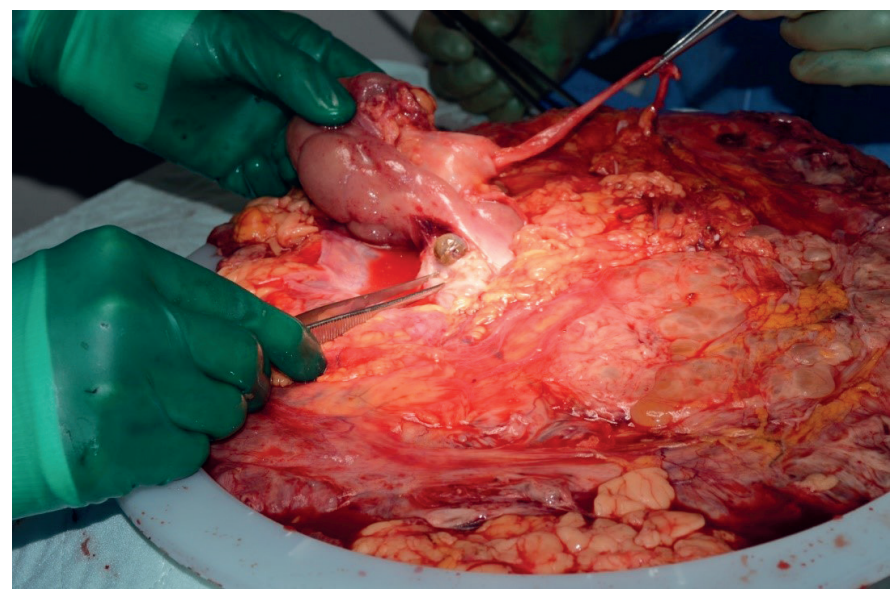

Figure 2. Gross examination of right sided kidney mass showing obliteration of lower pole of right kidney

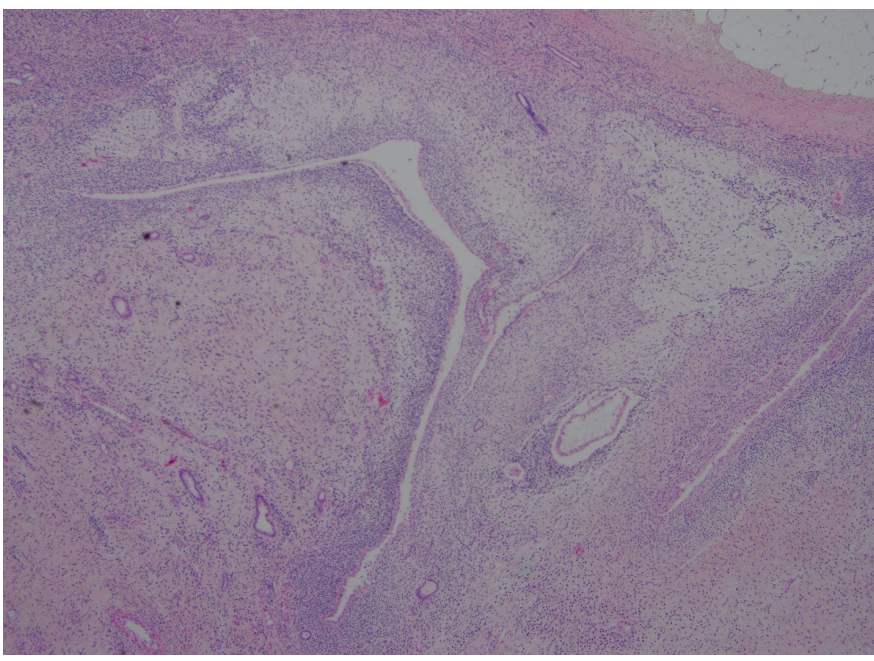

Figure 3. Microscopic specimen depicting stromal predominant wilms tumor 
based on well-studied risk-based regimens developed for the pediatric population (6). The implementation of this approach to adult Wilms' tumor has been previously shown to improve the overall outcome in adult patients $(7,8)$. Involvement of a pediatric oncologist can be an important step due to familiarity with such treatment protocols (9). Close monitoring and followup are essential in overall management of patients with adult Wilms' tumor. Treatment toxicity both from chemotherapy and radiation tends to be higher in adults (10). Cardiac, hematological and renal toxicity associated with chemotherapy is common and should be monitored during treatment. Patients may also suffer from infertility and secondary malignancies after radiation therapy (3).

Prior to the utilization of chemotherapy and radiation, the prognosis of adult Wilms' tumor was poor, with survival rates ranging from 18-27\% (7). Studies found similar overall survival by both NWTS favorable histology Wilms' tumor when comparing pediatric and adult patients. For adults specifically, the NWTS found overall survival at 5 years based on stage of disease to be: stage $1-100 \%$, stage $2-92 \%$, stage $3-70 \%$, and stage $4-73 \%$ (7). However, other case series have found that outcomes tend to be poorer for adults regarding overall survival. A recent study by Ali et al. (11) have found that, when comparing all stages, pediatric patients had much better 5-year overall survival when compared to adults. The author attributes this difference in survival to a combination of inadequate staging, treatment delay, and under treatment of adults in the general population (11).

Adult Wilms' tumor is a rare disease, in which diagnosis is dismal prior to the advent of pediatric treatment protocols for adult patients. The treatment of adult Wilms' tumor involves multi-drug chemotherapy with or without radiation, and adults tend to have higher rates of toxicity when compared to the pediatric population. The prognosis of adult Wilms' tumor has improved using pediatric protocols, however, in comparison to pediatric patients, conflicting data on outcomes is present when assessing the overall survival between the two populations. Further research is needed regarding treatment and prognosis of this rare disease process in the adult population.

\section{Ethics}

Informed Consent: Written consent was obtained from patient regarding use of case report for medical research.

Peer-review: Externally and internally peer-reviewed.

\section{Authorship Contributions}

Surgical and Medical Practices: S.P., G.C., Concept: G.C., Design: G.C., S.P., K.C., Analysis or Interpretation: G.C., S.P., K.C., L.A., Literature Search: G.C., K.C., L.A., Writing: G.C., K.C., S.P.

Conflict of Interest: No conflict of interest was declared by the authors.

Financial Disclosure: The authors declared that this study received no financial support.

\section{References}

1. Mitry E, Ciccolallo L, Coleman MP, Gatta G, Pritchard-Jones K; EUROCARE Working Group. Incidence of and survival from Wilms' tumour in adults in Europe: data from the EUROCARE study. Eur J Cancer 2006;42:2363-2368.

2. Kilton L, Mathews MJ, Cohen MH. Adult Wilms' tumour: a report of prolonged survival and review of literature. J Urol 1980;124:1-5.

3. Huszno J, Starzyczny-Slota D, Jaworska M, Nowara E. Adult Wilms tumourdiagnosis and current therapy. Cent European J Urol 2013;66:39-44.

4. Erginel B. Wilms Tumor and Its Management in a Surgical Aspect. In: van den Heuvel-Eibrink MM. Wilms Tumor [Internet]. Brisbane (AU): Codon Publications; 2016 Mar. Table 1. [The NWTS staging system]. https://www. ncbi.nlm.nih.gov/books/NBK373361/table/tab4_1/ doi: 10.15586/codon. wt.2016.ch4

5. Children's Oncology Group. AREN0532: Vincristine, dactinomycin, and doxorubicin with or without radiation therapy or observation only intreating younger patients who are undergoingsurgery for newly diagnosed stage I, stage II, or stage III Wilms' tumor (NCT00352534). https://clinicaltrials.gov/ ct2/show/NCT00352534. Date accessed 8/21/17.

6. Mahmoud F, Allen MB, Cox R, Davis R. Wilms Tumor: An Uncommon Entity in the Adult Patient. Perm J 2016;20:119-121.

7. Kalapurakal JA, Nan B, Norkool P, Coppes M, Perlman E, Beckwith B, Ritchey M, Breslow N, Grundy P, D'angio GJ, Green DM, Thomas PR. Treatment outcomes in adults with favorable histologic type Wilms tumor-an update from the National Wilms Tumor Study Group. Int J Radiat Oncol Biol Phys 2004;60:1379-1384.

8. Reinhard H, Aliani S, Ruebe C, Stöckle M, Leuschner I, Graf N. Wilms' tumor in adults: results of the Society of Pediatric Oncology (SIOP) 93-01/ Society for Pediatric Oncology and Hematology (GPOH) Study. J Clin Oncol 2004;22:4500-4506.

9. Segers $\mathrm{H}$, van den Heuvel-Eibrink MM, Pritchard-Jones $\mathrm{K}$, Coppes $\mathrm{MJ}$, Aitchison M, Bergeron C, de Camargo B, Dome JS, Grundy P, Gatta G, Graf N, Grundy P, Kalapurakal JA, de Kraker J, Perlman EJ, Reinhard H, Spreafico F, Vujanic G, Warwick AB; SIOP-RTSG and the COG-Renal Tumour Committee. Management of adults with Wilms' tumor: recommendations based on international consensus. Expert Rev Anticancer Ther 2011;11:1105-1113.

10. Reinhard $H$, Aliani $S$, Ruebe $C$, Stöckle $M$, Leuschner I, Graf N. Wilms' tumor in adults: results of the Society of Pediatric Oncology (SIOP) 93-01/ Society for Pediatric Oncology and Hematology (GPOH) Study. J Clin Oncol 2004;22;4500-4506.

11. Ali AN, Diaz R, Shu HK, Paulino AC, Esiashvili N. A Surveillance, Epidemiology and End Results (SEER) program comparison of adult and pediatric Wilms' tumor. Cancer 2012;118:2541-2551. 